\title{
Full Day School in an Effort to Improve the Quality of Education
}

\author{
Nurul Aisyah ${ }^{1}$ \\ Universitas Muhammadiyah Yogyakarta, Indonesia \\ Correspondence: nurulaisyahaisyah1991@yahoo.com
}

\begin{abstract}
Islamic schools are implementing full day school is almost spread to various regions in Indonesia. In addition to the output promising and school programs are laid out well, full day school is also an answer to concerns by parents about their children socially increasingly tense in the present era. Many false association that acted observation and child without parental control, on the other hand because parents are busy in a career that requires parents returned home late that afternoon after school child care is neglected. Full day school is a separate option for private schools in Indonesia, especially in Yogyakarta. Although the school has a full day school more hours spent in school, the output produced in accordance with the expected. However it is still said to be far from other countries. By using kaedah literature study, this article addresses the full day school as an effort to improve the quality of schools. Maximization of service, commitment, involvement of all parties, implementation of school programs that are clear, apply learning fun, extracurricular accordance with the interests of learners, scouting activities are directed, as well as the development of soft skills needed learners and strengthening technology in every activity into the basic aspects which must be done by a full day school.
\end{abstract}

Keywords: quality improvement; full day school 


\section{FULL DAY SCHOOL IN AN EFFORT TO IMPROVE}

\section{INTRODUCTION}

In Indonesia currently being intensively the issue of full day school is still under discussion the Minister of Education and Culture (Education) Muhadjir Effendy. Discourse full day school is expressed Muhadjir in Kompas.com (Tuesday, August 9, 2016) as the basis for the fulfillment of hours of character education in elementary and junior high schools, however Muhadjir will review related to the implementation of full day school system in schools in Indonesia, It is not far to achieving the quality of education in Indonesia, namely the emphasis on character education and general education.

Law on Sisdiknas No. 20 of 2003 Article 3, which states that "national education serves to develop the ability and form Character And civilization was dignified hearts Frame intellectual life of the nation, aims to review the development potential of learners in order to become Man of faithful and devoted shown God Almighty, noble, healthy, knowledgeable, skilled, creative, independent and Become Citizens As well as the responsible democratic " The depth studies related of full day school system in the State schools in Indonesia needs to be done to minimize the tension / noise in the community. Because why? Society tightened in because distribution of education in every region in Indonesia has not been reached.

Supiatin (Zazin, 2011) explains that the criteria for quality school characterized by the pillars of the quality of education that is universal and can be applied starting from the classroom to the maintenance of the building. And the most important components of quality is the underlying foundation of building a quality program include: vision, mission, beliefs and values of the school, objectives and critical success factors. Building a quality program include the following:

a) Customer focus.

b) Encouraging community involvement in the program total.

c) Develop a measurement system the added value of education.

d) The commitment of the school community.

e) Make improvements continuously.

Meanwhile, according to Juran (Juran \& Godfrey, 1998) the quality of products is the use of the product suitability (fitness for use) to meet the needs (customer needs) and customer satisfaction (customer satisfaction).

\section{METHOD}

The analysis in this paper do with methods of literary study. 


\section{FULL DAY SCHOOL IN AN EFFORT TO IMPROVE}

\section{DISCUSSION}

Full day school system is not a new discourse in the world of Islamic education. Full day school is a school that is preferred by many users of educational services. Moreover, because the output produced so promising, full day school system that has been adopted in some Islamic schools in Indonesia have progam school with good management, so it is not very surprising that students in elementary school and junior high school was enjoyed live School activity. Full Day School (Suwanda \& Soapatty, 2014) not curb students not to play and continuous learning, but in the Full Day School are also learning methods and media that includes classroom and nature, so students do not become bored. With the Full Day School system, the length of time that learning is not a burden for most of the time is used for time-time informal.

Full day school (Farid, 2009, p. 3) is a model of learning by adding the students' learning time from morning to evening. While the system (Robert G Murdick, 1991, p. 27) is a set of elements that make up a collection or procedures or charts processing seeking an objective part or a common goal by operating the data and / or goods at certain referral to produce information and / or energy and / or goods. The system according to Sidharta (Sidharta, 1995, p. 9) is the set of parts that are interconnected, which collectively achieve the same objectives. So the full day school system is a set of sets of parts that are interconnected to provide education with student learning models from morning to evening to reach a goal that is a good output.

Islamic schools what implementing full day school is almost spread to various regions in Indonesia. In addition to the output promising and school programs are well-structured, full-day school system is also an answer to concerns by parents about the association of their children increasingly tense in this era, such as promiscuity, rah-rah, a motorcycle gang, brawl up on involvement in illegal drugs. Many false association conducted observation and child without parental control, on the other hand for busy parents (father and mother) in a career that requires parents returned home late that afternoon after school child care is neglected. Another case if put children at Islamic schools that implement full day school system, in which children are always under the supervision of all the teachers and parents. And already there are school programs that make it easier for parents to dig up information about their child, school activities, as well as the attitude of even the child's personality can be explored by parents to the school.

Full day school system is not a system that is mediocre. Full day school system requires that schools have good programs that in the interest of the child at his age other than 
academic, extracurricular fields, scouting, leadership training and development field softskill other learners. Associated with the various programs offered by the school, then the school is running a full day school system must pay attention to the infrastructure that needs to be owned by the school, because the program will not run properly if there is no participation of the various parties and the lack of infrastructure support.

Was not stopped on infrastructure alone even HR (Human Resources) professionals must also be owned by the schools with a full day school. The realization that "works as an educator is worship that will flow even if we have to die" and "this job is a trust that must be at the waistband for the realization of the next generation of skilled and Sholih Sholihah".

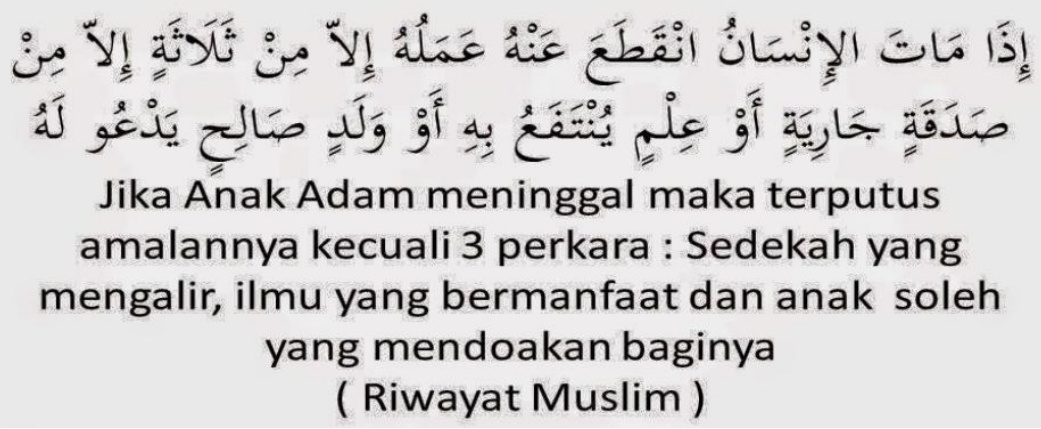

Thus, it will sensitize its human resources that work must be trustworthy and maximum. So no wonder if in various private schools based Islam in particular has a mandatory program for employees and teachers, Spiritual Accompaniment is done routinely every month or every week once. In management science we have met with Human Resource Management.

George R. Terry (George, 1997) in his book Principles of Management reveals there are six basic resources of management, which includes:
1. Men and Women
2. Materials
3. Machines
4. Methods
5. Money
6. Markets

Human resources listed in the first place. We need to realize that the man is what will drive an organization, moving their ideas to eventually be able to achieve what objectives they had set at the beginning. In management, the human factor is the most decisive.

Material is finished or half-finished material (raw material). Material in the mean is a substance / material to be transferred by educators (teachers) to learners. The infrastructure that supports that the material can be conveyed by pesera learners.

Machine or engine used to provide convenience or profit in work efficiency. Whereas, the method is the way in which teachers / school to school learning goals and objectives can 


\section{FULL DAY SCHOOL IN AN EFFORT TO IMPROVE}

be achieved. Money is one of the elements that can not be ignored. Money is an important tool for achieving the goal because the cost must always be calculated rationally, for example in school budgeting, in the payroll of the employees and teachers.

Market, which in education is more intended towards marketing student output / outcome to the users of educational services / public audience (market). In order for the market can be controlled by the quality of the output generated should correspond to the expected one that is learner (output) have Islamic character and be able to compete at the next level of schooling. So from here the learning process should take precedence, input processing into finished goods. School improvement can be initiated from maximizing the sixth aspect of the above resources

\section{Definition of strategy:}

Strategy (Johnson \& Scholes, 1999, hal. 10) is the direction and scope of an organization over the long term which achieve advantage for the organization thought its configuration of resources within a changing environment, to meet the needs of markets and to stakeholder espectations.

Another case with Quinn (Quinn, 1980) submitted, the strategy is

a strategy is the pattern or plan that integrates an organization's major goal, policies, and action sequences into a cohesive whole...

So strategy is the direction and scope of an organization over the long term which achieve advantage for the organization to meet the needs of markets and to stakeholder espectations.

Quality is always associated with considerable financial supplies and inputs (students) are good. According to Kartono (Kartono, 2015) An understanding of the effort to improve the quality (process) is dependent on money and students. Thus, Adams (Rasheed, 2000) defined that quality of school must meet the following dimentions: (1) Students ready to participate in learn; (2) A healty environment, the family supported; (3) The curriculum must be relevant; (4) The learning process through student-centered approach; and (5) The result of study that covers the knowledge, skills and attitudes and always associated with the national goal for education and participate positively in society.

In addition to the above five aspects of quality can also be achieved if as expected the users of it, then The success of the school can be seen from the following four aspects (Syafaruddin, 2005, p. 288):

1. Learners are satisfied with the services of the school (good services);

2. Parents of students are satisfied with the service of her son (real good services) 
3. The user or recipient graduates satisfied that accept graduates with high quality and according to expectations (good outcome);

4. Teachers and school employees are satisfied premises services (saticfaction work).

Satisfaction of the various parties would be the main thing that must be considered. User satisfaction of educational services and educational workers (teachers / employees) is a major goal in the organization here called the school. Teamwork (team work) is one thing that should also be done in all organizations is a common goal to provide satisfaction to stakeholders, so that cooperation is built will be light on its accomplishment. Creation and habituation doing good relations with stakeholders and users of educational services (internal customers and external customers) will speed up the development of the school even on maintaining the quality of schools.

There is a school-based Islamic private in Yogyakarta in deficits improve the quality applying the full day school system, there are several findings in full day school system this school (Aisyah, 2015), that is the five pillars to be used one Islamic school in Yogyakarta, which can be described as follows:

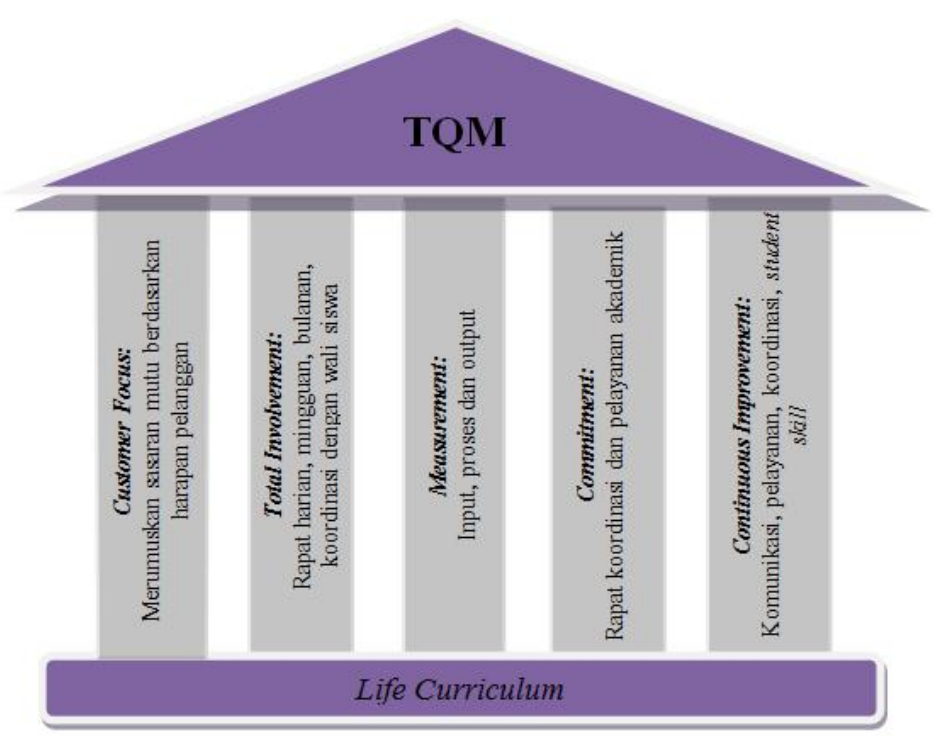

Picture 1. Five Pillars of TQM in Quality Improvement SMP Bina Anak Sholeh ( BIAS ) Yogyakarta

Five pillars above as the implementation of quality management improvement of the BIAS school. Which of the five pillars of TQM that have a foundation in life curriculum called Tawheed Integrated Curriculum (Curriculum integrated with monotheism), this curriculum comes alive when all parties, especially school teachers and employees of the 


\section{FULL DAY SCHOOL IN AN EFFORT TO IMPROVE}

curriculum applying the method of commanding the good and forbidding unjust in their daily life.

Strategies to improve the quality of schools with full day school system is a separate option for private schools in Indonesia, especially in Yogyakarta. Islamic schools are implementing full day school system including Mualimin, Mualimat, elementary and junior high BIAS, and many other schools.

Besides Yogyakarta, some schools are implementing the system FDS in Sidoarjo have significant influence. One of them is junior Jati Agung. Research (Suwanda \& Soapatty, 2014) conducted in this school have a significant outcome on student achievement. The data obtained in this study by distributing questionnaire, interviews, documentation and observation. The results of the data in this study will be analyzed using inferential statistics methods using linear regression formula. Research indicates that ( 1 ) Full Day School systems have a significant effect on student achievement Supreme Sidoarjo junior Teak ( 2 ) Full Day School will be able to influence the academic performance of students if the school adjust infrastructure tailored to the needs of students, curriculum, and teacher creativity state students.

As for the full day school system with the mention of another term that is integrated Islamic School, It would have spread to various regions in Indonesia. Although they have spent more hours in school than at home, the resulting output in accordance with the expected. However it is still said to be far from other countries. If you look at education in South Korea, the education system in south korea superior to Indonesia.

Quoted from mbctimes, this year the education system in South Korea ranked first. Study hours spent in school an average of 13 hours a day. Actually, the implementation of full day school system is the first step strategy to improve the quality of school which must be balanced with maximizing the service, commitment to a common goal, the involvement of stakeholders, support of all parties, the implementation of school programs is clear, apply learning exciting, extracurricular appropriate the hobbies and interests of learners, scouting activities are directed, as well as soft skill development needs of learners according to age.

If all the private schools with a full day school system can achieve success, generating the expected output. The policy of full day school system at every public school in the country worthy enacted, with a record of educational equity issues unresolved to be resolved first, then imposed a full day school system at every school in the country. 


\section{FULL DAY SCHOOL IN AN EFFORT TO IMPROVE}

Is a series of policy decisions or governmental action which has the aim of solving problems that impact is felt by many people. This policy is the result of the decision, it was decided before the implementation of full day school system in all elementary and junior high schools, Ministry of Education and its staff need to formulate in advance (policy adoption) with reviewing context comprehensively. Planning, organization, actuating and controlling (POAC) associated with the system to be applied can be carried out after the analysis of the context of actually obtained. 


\section{REFERENCES}

Aisyah, N. (2015). Peningkatan mutu sekolah Islam berwawasan internasional sekolah Islam terpadu Bina Anak Sholeh Yogyakarta. Yogyakarta: eprints UNY.

Farid, N. (2009). Hubungan antara pelaksanaan pendidikan full day school dengan perilaku sosial keagaman di luar sekolah. Surabaya: IAIN Sunan Ampel.

Fidler, B. (2002). Strategic management for school development: Leading your school's improvement strategy. London: A Sage.

George, R. (1997). Principles of Management.

Johnson, G. \& Scholes, C. (1999). Exploring corporate strategy: Text and sases. Harlow: Pearson Education.

Juran, J., \& Godfrey, A. (1998). Juran's quality handbook (5th ed). New York: McGraw-Hill.

Kartono. (2015). Social capital and quality improvement at the junior high school VIP Al-Huda in Kebumen, Central Java, Indonesia. EDUCARE, 147.

Kompas.com (Selasa, 9 Agustus 2016)

Quinn, J. (1980). Strategy for change: Logical Incrementalism. Homewood: Irwin.

Rasheed, S. (2000). Defining quality in education. New York: UNICEF.

Robert G Murdick, d. ( 1991). Sistem informasi untuk manajemen modern. Jakarta: Erlangga.

Sidharta, L. (1995). Pengantar sistem informasi bisnis. Jakarta: P.T. ELEX Media Komputindo.

Suwanda \& Soapatty. (2014). Pengaruh sistem sekolah sehari penuh (full day school) terhadap prestasi akademik siswa SMP Jati Agung Sidoarjo. Kajian Moral dan Kewarganegaraan Nomor 2 Volume 2 Tahun 2014. P:719-733, 719-733.

Syafaruddin. ( 2005). Manajemen lembaga pendidikan Islam. Jakarta: Ciputat press.

Walgito, B. (2003). Psikologi sosial, suatu pengantar. Yogyakarta: Penerbit ANDI.

Zazin, N. (2011). Gerakan menata mutu pendidikan: Teori \& aplikasi. Yogyakarta: Ar-ruzz Media. 